\title{
Anti-NMDA Receptor Encephalitis Presenting with Acute Psychosis
}

\author{
Akut Psikoz Bulguları ile Başvuran Anti-NMDA Reseptör Ensefalitli \\ Bir Olgu Sunumu
}

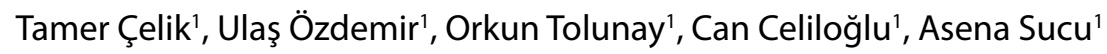 \\ ${ }^{1}$ Department of Pediatrics, Adana City Training and Research Hospital, Adana, Turkey
}

Cite this article as: Çelik T, Özdemir U, Tolunay O, Celiloğlu C, Sucu A. Anti-NMDA receptor encephalitis presenting with acute psychosis. J Pediatr Inf 2019;13(3):e132-e135.

\section{Abstract}

Autoimmune encephalitis cases are diagnosed more frequently with the increase in the number of investigative facilities and the raising awareness of clinicians. Anti-N-methyl-D-aspartate (NMDA) receptor encephalitis is the most common type of autoimmune encephalitis in childhood. Early diagnosis of the disease contributes significantly to prognosis. Diagnosis is made by detecting antibodies against anti-NMDA receptors in the cerebrospinal fluid (CSF) and serum. Central nervous system imaging and electroencephalography (EEG) findings are not specific to the disease and may have supportive role in diagnosis. Herein, we report a 15 year-old-girl who presented with fever, psychotic symptoms and unconsciousness and was diagnosed with anti-NMDA receptor encephalitis.

Keywords: Anti-NMDA receptor encephalitis, child, autoimmune disease

\section{Introduction}

Autoimmune encephalitis is a disease that occurs against neuronal antigens as a result of immune response and in which cognitive inefficiency and behavioral disorders and epileptic attacks may be seen. It is a significant subgroup in pediatric encephalitis etiology. Anti-NMDA receptor encephalitis is the most frequently diagnosed of all autoimmune encephalitis. It is seen in the literature that both other types of autoimmune encephalitis and anti-NMDA receptor encephalitis receive increasing diagnosis thanks to having put forth different clinical
Öz

Günümüzde tetkik imkanlarının çoğalması ve klinisyenlerin konuya dair farkındalığının artması ile otoimmün ensefalit hastaları daha sık tanı alabilmektedir. Anti-N-metil-D-aspartat (NMDA) reseptör ensefaliti, çocukluk çağında en sık görülen otoimmün ensefalit tipidir. Hastalığa erken dönemde tanı konulması, prognoza önemli oranda katkı sağlamaktadır. Beyin omurilik sıvısında ve serumda saptanan anti-NMDA reseptörlerine karşı gelişen antikorların saptanması ile tanı konulmakta, santral sinir sistemi görüntülemeleri ve elektroensefalografi (EEG) bulguları hastalığa özgün olmayıp, tanıda destekleyici özellik arz edebilmektedir. Ateş, psikotik semptomlar, bilinç kaybı ile başvuran ve anti-NMDA reseptör ensefaliti tanısı alan 15 yaşındaki kız olgu sunulmuştur.

Anahtar Kelimeler: Anti-NMDA reseptör ensefaliti, çocuk, otoimmün hastalık

presentation forms of the diseases and diversified examination possibilities. This article presents an adolescent female patient diagnosed with anti-NMDA receptor encephalitis following a presentation suggesting psychiatric symptoms and toxin exposure.

\section{Case Report}

A 15-year-old female patient, with no prior history of any disease, had suddenly started experiencing body spasms, paresthesia, and meaningless speech two weeks prior to admission. Medical treatment was given to the patient who was

Yazışma Adresi/Correspondence Address

\section{Can Celiloğlu}

Adana Şehir Eğitim ve Araştırma Hastanesi, Çocuk Sağlığı ve Hastalıkları Kliniği, Adana-Türkiye

E-mail: canceliloglu@yahoo.com 
thought to be having a nervous breakdown in the psychiatry department. The patient whose spasms increased afterwards was hospitalized in the state hospital she applied, and since fever was started to be observed in this period, the patient was transferred to our hospital for organic etiology investigation. The patient was admitted to pediatric intensive care with a preliminary diagnosis of meningoencephalitis due to the fact that she was unconscious and her general condition was bad. Initial examination of the patient was as follows: body temperature: $37^{\circ} \mathrm{C}$, pulse: 90 pulse/min, respiratory rate: $26 /$ min, subcutaneous oxygen saturation in room air: $92 \%$. The patient was evaluated as severe encephalopathy during her physical examination which revealed unconsciousness, spontaneous respiration, incomprehensible sounds, no eye opening response to a painful stimulant, and lip licking movements. Pathology was not detected in cerebral tomography and diffusion magnetic resonance (MR) imaging of the patient. Glucose was found $73 \mathrm{mg} / \mathrm{dL}$ and protein $14 \mathrm{mg} / \mathrm{dL}$ in the cerebrospinal fluid (CSF) examinations of the patient. No cells were seen in CSF microscopy. Growth was not found in CSF culture. The patient was started on intravenous acyclovir, ceftriaxone and clarithromycin treatment by ordering Herpes Simplex virus (HSV) and polymerase chain reaction (PCR) tests in CSF and brucella agglutination, HSV immunoglobulin M (IgM), Epstein-Barr virus antibodies, Cytomegalovirus (CMV) IgM, toxoplasma IgM, and rubella IgM examinations in serum. CSF HSV PCR examination was negative, serum brucella agglutination, HSV IgM, Mycoplasma IgM, EBV VCA-IgM, CMV $\lg M$, Toxoplasma IgM, Rubella IgM examinations were found negative. Slow waves in EEG corrected for age were evaluated compatible with encephalitis. Levetiracetam was administered to the patient as anticonvulsant who had generalized tonic-clonic convulsions in her follow-up. Haloperidol was added to the treatment of the patient who started suffering from choreoathetosis.

When patient history was deepened, it was found that prior to the commencement of the complaints, the patient had travelled to a friend living in another city without her parents, and complaints such as headaches, vomiting and meaningless speech started once she returned from her travel. Toxicologic examinations were performed on the patient who was thought to have run away from home for personal reasons found out in anamnesis; however, no pathological substance was found. No pathology was seen in the cerebral MR imaging taken during follow-up. Ammoniac, thyroid autoantibodies, serum antinuclear antibody oriented at autoimmunity, anti-deoxyribonucleic acid antibody, celiac disease serology, complement 3 and 4 values were taken for etiology from the case whose CSF and serum examinations revealed no pathologies and in whom empirical antibiotic treatment did not provide any significant recovery in her clinic. CSF NMDA receptor antibody taken form the case was detected positive. The patient underwent malignancy scans including serum alpha-feto protein, cancer antigen (CA) 15-2, CA 19-9, carcinoembryonic antigen examinations, and abdominal and pelvic ultrasonography and thoracic ultrasonography due to potential paraneoplastic syndrome. The patient, in whom malignancy was excluded with oncological markers and radiological examinations, received intravenous immunoglobulin (IVIG) and when expected response was not received to the treatment, pulse steroid treatment was started. Plasmapheresis was implemented on the case whose follow up demonstrated no distinct amelioration during neurological examination. During intensive care monitoring of the patient, mechanical ventilation support was needed for two weeks owing to hypoventilation. The patient regained conscious at the end of the second month after having received IVIG and pulse steroid treatments again after plasmapheresis. From this point on, patient's recovery quickened and was discharged in the third month of hospitalization with normal neurological findings, and outpatient follow-ups were planned.

\section{Discussion}

The role of autoimmunity has been better understood in the etiology of encephalitis in recent years (1). In the etiology of newly-developed, resistant status epilepticus cases, autoimmune encephalitis (19\%) has been most frequently detected after the cryptogenic group (52\%) (2). Anti-NMDA receptor encephalitis is the most widely diagnosed one among childhood autoimmune encephalitis $(3,4)$. In an etiological study conducted in the USA with 761 encephalitis cases, antiNMDA positivity has been detected at a higher rate than any other microbiological agents (like enteroviruses, herpes virus, and etc.) (5).

Pathology in anti-NMDA receptor encephalitis is basically the presence of pathological autoantibody adhering to the NMDA receptor found in the brain (6). It was first defined in 2007 as a clinical picture related to ovarian teratoma (7). It has been reported in an increasing number of studies that anti-NMDA receptor encephalitis can develop without an underlying malignancy and that NMDA receptor positivity can be determined in certain cases who had suffered herpes virus encephalitis $(8,9)$. Our patient's history did not involve herpes encephalitis. While evaluating cases suspected for autoimmune encephalitis, these matters must be kept in mind.

It has been reported that $40 \%$ of the cases with anti-NMDA receptor encephalitis is observed in the pediatric age group (5). Anti-NMDA receptor encephalitis picture involves headache, fever and flu-like symptoms followed by psychiatric symptoms such as anxiety, agitation and hallucinations within 
days, and sleep disorder, memory loss, seizure, regression in conscious, stupor, dyskinesia, autonomous nervous system findings (hyperthermia, tachycardia, bradycardia) and hypoventilation may accompany (10). It has also been indicated that psychiatric symptoms in adolescents close to adulthood and in adults and neurologic symptoms like eclampsia and dyskinesia in children are at the forefront in anti-NMDA receptor encephalitis (11).

We excluded HSV encephalitis due to the fact that there was no pathology on cerebral MR imaging of the patient, EEG was not compatible with HSV encephalitis, and CSF HSV PCR examinations were negative. Exclusion of autoimmune diseases was made possible by not having detected any pathologies in serologic examinations oriented at the thyroid autoantibodies, celiac serology and systemic lupus erythematosus of the case. Malignancies and paraneoplastic syndromes were excluded since there was no weight loss and night sweating in anamnesis, lymphadenomegaly and hepatomegaly were not observed in systemic examination, space occupying lesions were not found in imagings, and serum malignancy markers were negative. Diagnostic criteria in anti-NMDA receptor encephalitis include the detection of immunoglobulin $G$ class antibodies that develop against NMDA in serum and cerebrospinal fluid and the exclusion of other probable agents (4). Following the exclusion of all other probable diagnoses, we confirmed the diagnosis when CSF NMDA receptor antibody was found positive.

It has been reported that anti-NMDA receptor encephalitis cases mostly require intensive care (at a rate of $69 \%$ in non-malignancy cases and 85\% in malignancy presence) (12). Mechanical ventilation support was needed in our case in the intensive care. In etiology, tumors are rare in children, but their frequency increases with age (13). No pathology was detected in malignancy examinations of our case. It has been stated that slowed waves and irregularities not associated with involuntary movements can be frequently seen and also epileptic attacks, though less frequently, can be observed in EEG (13).

Intravenous methylprednisolone, IVIG, plasmapheresis and tumor surgery, if present are applied as first-line treatments and second-line treatments (rituximab and cyclophosphamide) are started in cases that do not ameliorate (14). In a cohort study conducted on anti-NMDA receptor encephalitis in children regarding the treatment process, the authors have reported that immunosuppressive treatment for more than 12 months was given to $40 \%$ of the cases (6). Our case responded well to first-line treatments, hypoventilation recovered, and convulsion was not seen again. In a multi-variate analysis of 501 cases with anti-NMDA in the literature, factors significantly contributing to prognosis have been determined as early onset of treatment and no need for intensive care (12). Toxicologic analyses were performed in our patient due to anamnesis of running away from home and possible exposure to illicit substances and after toxicological investigations were found negative, autoimmune encephalitis tests were ordered and first-line immunomodulator treatment was started; however, intensive care requirement significantly prolonged the hospitalization period.

Even though there are various characteristic findings of anti-NMDA receptor encephalitis and other autoimmune encephalitis distinguishable on EEG and MR examinations, they may present with infectious encephalitis-like symptoms and clinical course. Autoimmune encephalitis should be brought to mind in cases with suspicious history, a severe clinical course and insufficient response to treatment, and NMDA receptor antibody and other autoantibody tests should be ordered and treatment should be started at an early period.

Informed Consent: Informed consent was obtained.

Peer-review: Externally peer-reviewed.

Author Contributions: Consept - TÇ, OT; Design - CC, OT, UÖ; Supervision - TÇ; References - TÇ, OT, CC; Data Collection and/or Interpretation - CC, UÖ, OT, AS; Analysis - TÇ, OT; Literature Search AS, CC; Writing - CC, OT; Critical Review -TÇ.

Conflict of Interest: The authors have not reported a conflict of interest.

Financial Disclosure: There is no financial support in this study.

\section{References}

1. Sakpichaisakul K, Patibat L, Wechapinan T, Sri-Udomkajrorn S, Apiwattanakul $M$, et al. Heterogenous treatment for anti-NMDAR encephalitis in children leads to different outcomes 6-12 months after diagnosis. J Neuroimmunol 2018;324:119-25

2. Gaspard N, Foreman BP, Alvarez V, Cabrera Kang C, Probasco JC, et al. New-onset refractory status epilepticus: Etiology, clinical features, and outcome. Neurology 2015;85:1604-13.

3. Granerod J, Ambrose HE, Davies NW, et al. Causes of encephalitis and differences in their clinical presentations in England: a multicentre, population based prospective study. Lancet Infect Dis 2010;10:835-44.

4. Sai Y, Zhang X, Feng M, Tang J, Liao H, Tan L. Clinical diagnosis and treatment of pediatric anti-N-methyl-D-aspartate receptor encephalitis: A single center retrospective study. Exp Ther Med 2018;16:1442-8.

5. Gable MS, Sheriff H, Dalmau J, Tilley DH, Glaser CA. The frequency of autoimmune $\mathrm{N}$-methyl-Daspartate receptor encephalitis surpasses that of individual viral etiologies in young individuals enrolled in the California Encephalitis Project. Clin Infect Dis 2012;54:899-904.

6. Brenton JN, Kim J, Schwartz RH. Approach to the management of pediatric-onset anti-N-methyl-d-aspartate (anti-NMDA) receptor encephalitis: a case series. J Child Neurol 2016;31:1150-5.

7. Dalmau J, Tuzun E, Wu HY, et al. Paraneoplastic anti-N-methyl-Daspartate receptor encephalitis associated with ovarian teratoma. Ann Neurol 2007;61:25-36.

8. Salehi $N$, Yuan AK, Stevens $G$, Koshy R, Klein WF. A case of severe anti-Nmethyl $D$-aspartate (anti-NMDA) receptor encephalitis with refractory autonomic instability and elevated intracranial pressure. Am J Case Rep 2018;19:1216-21. 
9. Dalmau J, Rosenfeld MR. Paraneoplastic and autoimmune encephalitis. 2018. https://www.uptodate.com/contents/paraneoplastic-and-autoimmune-encephalitis. (son erişim tarihi: 08.02.2019)

10. Maccaferri GE, Rossetti AO, Dalmau J, Berney A. Anti-N-methyl$D$-aspartate receptor encephalitis: a new challenging entity for consultation-liaison psychiatrist. Brain Disord Ther 2016;5:1000215.

11. Titulaer MJ, McCracken L, Gabilondo I, Armangue T, Glaser C, lizuka T, et al. Treatment and prognostic factors for long-term outcome in patients with anti-NMDA receptor encephalitis: an observational cohort study. Lancet Neurol 2013;12:157-65.
12. Florance-Ryan N, Dalmau J. Update on anti-N-methyl-D-aspartate receptor encephalitis in children and adolescents. Curr Opin Pediatr 2010;22:739-44.

13. Armangue T, Leypoldt F, Malaga I, Raspall-Chaure M, Marti I, Nichter C, et al. Herpes simplex virus encephalitis is a trigger of brain autoimmunity. Ann Neurol 2014;75:317-23.

14. Kong SS, Chen YJ, Su IC, Lin JJ, Chou IJ, Chou ML, et al. Immunotherapy for anti-NMDA receptor encephalitis: experience from a single center in Taiwan. Pediatrics and Neonatology 2019; 60:417-22. 